\title{
Pleuropericardial Effusion Tuberculosis
}

\author{
Afni Fatmasari ${ }^{1}$, Fauzar ${ }^{2}$
}

\begin{abstract}
Abstrak
Pleuropercardial Effusion Tubercullosis adalah suatu keadaan dimana meningkatnya jumlah cairan di kavum pleura dan rongga perikardium yang disebabkan oleh infeksi Mycobacterium tubercullosis. Keadaan ini disebut tuberkulosis ekstra-paru dan merupakan kasus yang jarang terjadi. Telah dilaporkan laki-laki 57 tahun dengan keluhan utama sesak nafas sejak 1 bulan yang meningkat 1 minggu sebelum masuk rumah sakit. Batuk dan berkeringat malam sejak 9 bulan yang lalu, sudah dilakukan pemeriksaan BTA sputum dengan hasil negatif yang tidak sembuh dengan pemberian anti biotik. Pada pemeriksaan fisik dan rontgent dada terdapat efusi pleura dan kardiomegali, dari ekokardiografi terdapat efusi perikardium. Cek ADA pada cairan efusi perikardium didapatkan hasil 168,2 U/L, analisis cairan pleura yaitu eksudat, LDH 275, jumlah sel 600, MN $60 \%$, dan BTA cairan pleura negatif. Pasien diterapi dengan obat anti tuberkulosis kategori 1 selama 9 bulan dan kortikosteroid.
\end{abstract}

Kata kunci: pleuropercardial effusion, efusi pleura, efusi perkardium, tuberkulosis ekstra paru

\begin{abstract}
Pleuropericardial Effusion Tubercullosis is a condition in which there is an increase of fluid in the pleural cavity and pericardial sheath that is caused by Mycobacterium Tubercullosis infection. This condition is also called an extrapulmonary tuberculosis and is a rare case. A 57-year-old male patient had been reported with a major complaint of shortness of breath since 1 month that increased in intensity since 1 week before admission to the hospital.in addition, the patient had suffered a cough and night sweat since 9 months ago. Sputum acid-fast bacilli examination was then carried out with negative results. The symptoms could not be cured with antibiotics. Upon physical examination and chest $x$-ray, there were pleural effusions and cardiomegaly. From echocardiography, there was pericardium effusion. ADA test on pericardial effusion fluid resulted in 168,2 U/L, pleural fluid analyze was exudates, $L D H 275$, cell count $600, M N 60 \%$, and plural fluid acid-fast bacilli was negative. Patient was treated with anti tuberculosis drug first category for 9 months and corticosteroid.
\end{abstract}

Keywords: pleuropercardial effusion, pleural effusion, pericardial effusion, extrapulmonary tubercullosis

Affiliasi penulis: 1. Program Pendidikan Dokter Spesialis-1 Penyakit Dalam FK Unand, 2. Subbagian Pulmonologi Bagian IImu Penyakit Dalam FK Unand/RSUP M Djamil Padang.

Korespondensi: pibipd@yahoo.comTelp: 0751-37771

\section{PENDAHULUAN}

Pleuropericardial effusion tuberculosis adalah suatu keadaan dimana meningkatnya jumlah cairan di kavum pleura dan rongga perikardium yang disebabkan oleh infeksi Mycobacterium tubercullosis. Efusi pleura awalnya terlihat sebagai efusi yang serosantokrom dan bersifat eksudat yang kebanyakan terjadi sebagai komplikasi tuberkulosis paru melalui fokus sub pleura yang robek atau melalui aliran kelenjar getah bening. Cairan efusi sangat sedikit mengandung kuman tuberkulosis namun terjadi reaksi hipersensitivitas terhadap tuberkuloprotein. Pengobatan dengan obat anti tuberkulosis dapat menyebabkan cairan efusi dapat diserap kembali dan umumnya cairan dapat diresolusi dengan sempurna, tapi kadang dapat diberikan kortikosteroid sistemik selama 2 minggu dengan dosis tapering-off., ${ }^{1,2}$

Efusi pericardium tuberkulosis dapat terjadi secara hematogen, limfogen ataupun penyebaran langsung. Perikarditis tuberkulosis sering tanpa TB paru maupun TB di luar paru. Penyebaran tersering karena infeksi di nodus mediastinum, langsung 
masuk ke perikardium, terutama di sekitar percabangan trakeobronkial. ${ }^{3}$ Efusi perikardium menyebabkan peningkatan tekanan rongga perikardium sehingga terjadi kompresi jantung; tekanan diastolik meningkat sama dengan tekanan rongga perikardium. Kondisi tersebut akan menyebabkan pengisian jantung terganggu, tekanan vena sistemik menyebabkan tanda gagal jantung kanan (distensi vena jugularis, hepatomegali, dan edema perifer), sedangkan peningkatan vena pulmonalis menyebabkan bendungan paru. Penurunan pengisian ventrikel pada fase diastolik menyebabkan penurunan isi sekuncup dan curah jantung. ${ }^{4}$ Menurut WHO dalam Beidokhty (2016) pemberian OAT pada perikarditis tuberkulosis sama dengan tuberkulosis lainnya yaitu OAT kategori 1 yang terdiri dari Rifamfisin, $\mathbf{I N H}$, Pirazinamid dan etambutol selama 8 inggu setiap hari, dilanjutkan fase intermiten yaitu rifamfisin dan INH tiga kali seminggu sampai 9 bulan. ${ }^{5}$

\section{KASUS}

Seorang pasien laki-laki usia 57 tahun dirawat di bangsal Penyakit Dalam RSUP M Djamil Padang dengan keluhan utama sesak nafas sejak 1 bulan yang meningkat 1 minggu sebelum masuk rumah sakit. Kaki pasien disadari sembab sejak 3 hari yang lalu. Pasien juga mengeluhkan batuk tidak berdahak, berkeringat malam, penurunan berat badan sejak 9 bulan yang lalu. Pasien juga mengeluhkan nafsu makan yang menurun dan badan terasa lemah. Pasien sudah berobat ke dokter, sudah dilakukan pemeriksaan dahak dengan hasil negatif tuberkulosis, diberi anti biotik dan obat batuk namun tidak sembuh. Pasien dilakukan pemeriksaan ekokardiografi karena adanya kardiomegali dan kaki sembab dengan hasil efusi perikardium.

Pada pemeriksaan fisik didapatkan adanya peningkatan JVP, suara nafas yang menghilang setinggi torakal VII ke bawah pada paru kiri dan kanan, ronki basah halus tidak nyaring di basal kedua paru, pinggang jantung ada, letak iktus yang tidak sama dengan batas jantung, suara jantung yang menjauh, hepatomegali dan pitting edema.
Pada pemeriksaan laboratorium didapatkan hemoglobin 10,3 gr/dl, leukosit 9.300/mm3, hematokrit $32 \%$, trombosit 439.000/mm3, diffcount 0/2/1/87/10/0, LED 87 mm/jam.

Hasil ekspertise rontgent dada adanya kardiomegali dengan efusi pleura bilateral.

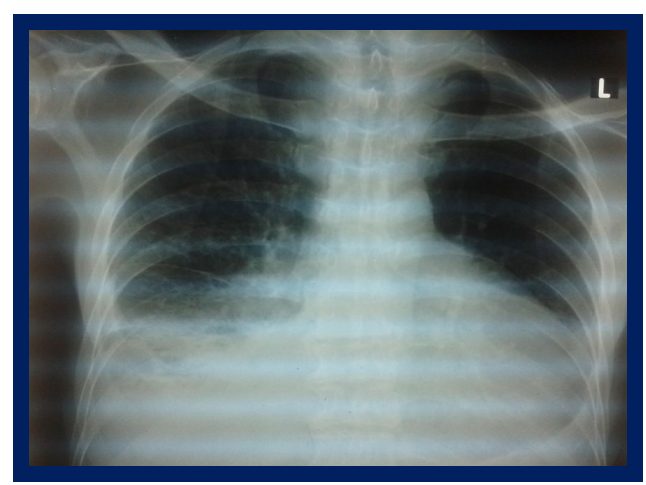

Gambar 1. Foto dada

Pemeriksaan Ekokardiografi mendapatkan adanya efusi perikardium inferobasal, laterobasal, septal basal dengan diameter 1-2 cm, ejection fraction 19,8\%, kontraktilitas ventrikel kanan dan kiri menurun, disfungsi diastolik dan hipokinetik global.

Pada pasien dilakukan perikardiosintesis dengan tuntunan USG untuk cek ADA (Adenosin Deaminase) cairan perikardium dengan hasil 168,2 $\mathrm{U} / \mathrm{L}$ (keterangan, $>40 \mathrm{U} / \mathrm{L}=\mathrm{TB}$ ). Analisis cairan pleura didapatkan jumlah sel 600, MN $60 \%$, Glukosa 128, total protein 4,2, LDH 275, PMN $40 \%$, rivalta positif, dengan kesan eksudat. Sedangkan BTA cairan pleura negatif.

\section{PEMBAHASAN}

Telah dirawat pasien laki-laki usia 57 tahun dengan diagnosis akhir Pleuropericardial Effusion Tubercullosis. Pada pasien ini didiagnosis sebagai Pleuropericardial Effusion Tubercullosis ditegakkan berdasarkan anamnesis dimana didapatkan keluhan sesak nafas yang dirasakan sejak 1 bulan sebelum masuk rumah sakit namun dirasakan meningkat sejak 1 minggu. Pasien juga mengeluh adanya kaki sembab, berkeringat malam, penurunan nafsu makan, penurunan berat badan dan batuk yang tidak sembuh dengan pemberian anti biotik dan obat batuk. 
Pada pemeriksaan fisik didapatkan suara nafas menghilang dari ruang inter kostal VII ke bawah paru kiri dan kanan, kardiomegali, pinggang jantung ada, dan suara jantung yang menjauh.

Pada pemeriksaan laboratorium ditemukan leukosit yang normal dengan laju endap darah yang meningkat. Sedangkan dari pemeriksaan radiologi ditemukan adanya kardiomegali dengan efusi pleura bilateral. Pada ekokardiografi ditemukan adanya efusi perikardial.
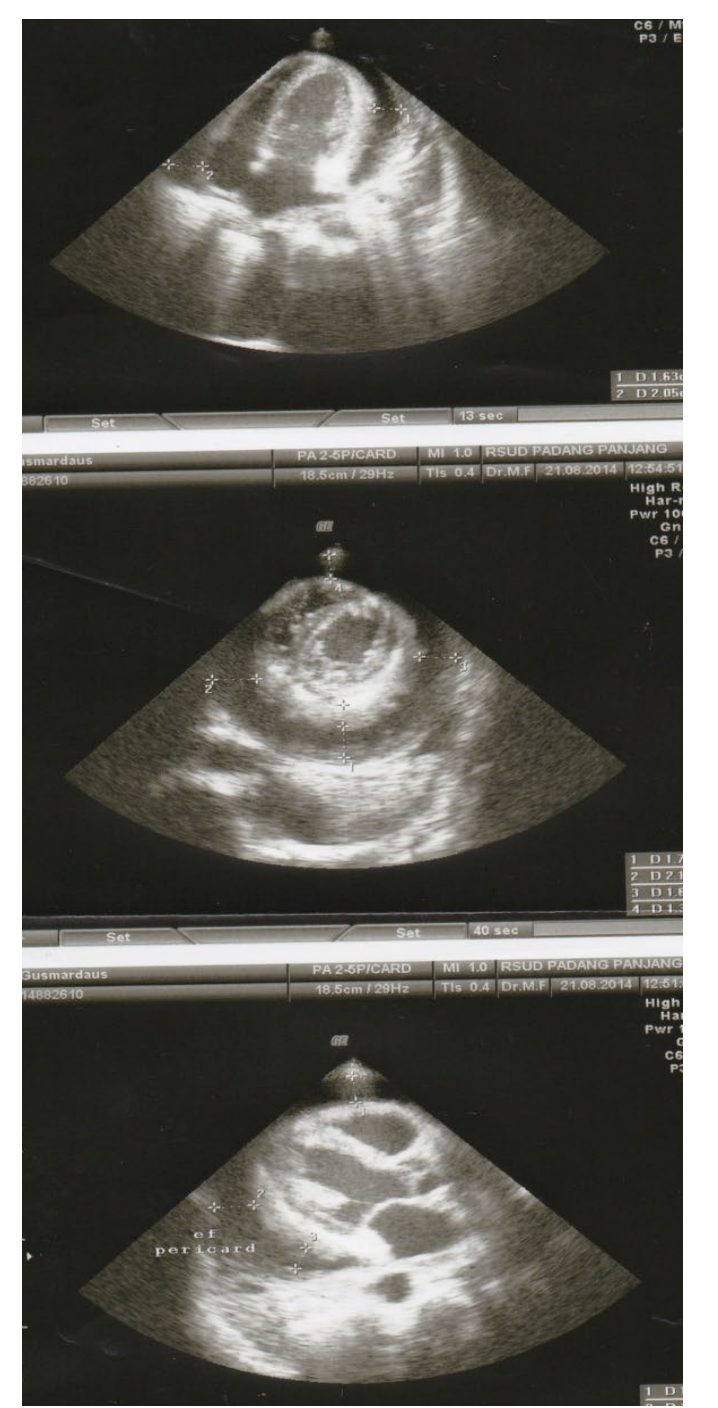

Gambar 2. Ekokardigrafi

Pasien ini sudah mengeluhkan adanya gejala konstitusi dari tuberkulosis sejak 9 bulan yang lalu. Pasien melakukan pemeriksaan darah, sputum serta radiologi yang semuanya tidak mendukung ke arah infeksi tuberkulosis. Hal ini membuat penanganan selanjutnya pada pasien tidak lagi diarahkan pada penelusuran tuberculosis, namun karena pasien mengeluhkan kaki sembab sejak 3 hari yang lalu maka dilakukan pemeriksaan ekokardiografi dengan hasil efusi perikardium. Adanya klinis yang sangat mendukung, maka penyebab efusi perikardium pada pasien dipikirkan adalah karena tuberkulosis.

Efusi perikardium tuberkulosis sekitar $1 \%$ dari jumlah kasus tuberkulosis dengan angka kematian 3$40 \%$. Efusi perikardium yang berlanjut menjadi tamponade jantung dan perikarditis konstriktif merupakan 2 penyebab kematian tersering. Terapi dengan anti tuberkulosis memberikan prognosis yang baik. Seharusnya pada pasien dilakukan analisis cairan perikardium, namun karena jumlah cairan yang berhasil diambil hanya $9 \mathrm{cc}$, maka diputuskan untuk dilakukan pemeriksaan Adenosis Deaminase (ADA) yang lebih sensitif mendiagnosis tuberkulosis. Sedangkan dari analisis cairan pleura sesuai dengan gambaran tuberkulosis dimana sesuai dengan kriteria lights disimpulkan cairan adalah eksudat. ${ }^{6}$

Pada pasien telah dilakukan pemeriksaan basil tahan asam pada sputum dengan hasil negatif yang tidak mendukung diagnosis tuberkulosis. Mycobacterium tuberculosis diperkirakan langsung dari nodus mediastinum sekitar percabangan trakeobronkial atau rupturnya kelenjar getah bening sub karina yang menyebar secara limfogen ataupun hematogen. Pada pasien telah dilakukan pemeriksaan BTA cairan efusi pleura yang hasilnya negatif. Hal ini terjadi karena jumlah kuman tuberkulosis sedikit dalam cairan efusi pleura. Untuk itu pemeriksaan ADA lebih dianjurkan pada cairan efusi perikardium maupun pleura. ${ }^{7}$

Menurut pedoman tatalaksana tuberkulosis, efusi perikardium dan efusi pleura yang disebabkan oleh infeksi kuman Mycobacterium tubercullosis dikategorikan sebagai tuberkulosis ekstra paru berat. Pasien diterapi dengan obat anti tuberkulosis kategori satu. Terapi pada pasien minimal 9 bulan dan juga ditambahkan steroid untuk mencegah reakumulasi cairan pada efusi pleuroperikardial, mencegah inflamasi dan perikarditis konstriktiva, serta menurunkan angka mortalitas. 1,2,5 Keluhan sesak dan batuk pada pasien berkurang setelah tiga hari mendapat terapi. 


\section{SIMPULAN}

Efusi Pleuroperikardial tuberculosis merupakan suatu infeksi Mycobacterium tuberculosis ekstra pulmoner yang insidennya jarang terjadi. Infeksi ini dapat diterapi dengan obat anti tuberculosis minimal 9 bulan yang memberikan prognosis baik dan menurunkan angka mortalitas.

\section{DAFTAR PUSTAKA}

1. Ajmal B, ljaz K, Mahmood KT. Management of tuberculous pleural effusion. J Biomed Sci and Res. 2011; 3 suppl 1:302-7.

2. Halim H. Penyakit-penyakit pleura. Dalam: Setiadi s, Alwi I, Sudoyo A, Simadibrata M, Setiyohadi B, Syam AF, editor (penyunting). Buku ajar IImu Penyaki Dalam. Edisi ke-6. Jakarta: Interna Publishing; 2014. hlm.1631-9.

3. Adler $Y$, Charron $P$, Imazio M, Badano L, Bogaert $\mathrm{J}$, Brucato $\mathrm{A}$, et al. ESC guidelines for the diagnosis and management of pericardial diseases. European Heart Journal. 2015;36 suppl 42:26-8.

4. Metaxas E, Kotsifas K, Tatsis G, Simpsiris P, Ntanos I, Tsoukalas G. Tuberculous pericarditis: Three cases and brief review. Monaldi Arch Chest Dis. 2010;73 suppl 1:44-50.

5. Beidokhty AA, Norouzi Z, Amiri A, Almasian M, Azadi A, Kheirollahi AR. Pericardial tuberculosis with an emphasis on empiric therapy in endemic areas for tuberculosis. International Journal of Mycobacteriology. 2016;6 suppl 7:1-5.

6. Sainani G, Sainani R. Tuberculous pericardial effusion. Indian Journal of Clinical Practice. 2012; 22 suppl 8:371-6.

7. Stevanovic G, Pelemis $M$, Pavlovic $M$, Lavadinovic L, Dakic Z, Milosevic I, et al. Significance of adenosine deaminase serum concentrations in the diagnosis of extrapulmonary tuberculosis. Journal of IMAB. 2011;17 suppl 1:130-4. 